\title{
KAJIAN JENIS DAN POPULASI TIKUS DI PERKEBUNAN NANAS PT GREAT GIANT FOOD TERBANGGI BESAR, LAMPUNG TENGAH
}

\author{
Ahmad Aziz Alfi Husein, Solikhin \&Lestari Wibowo \\ Jurusan Agroteknologi Fakultas Pertanian Universitas Lampung \\ Jl. Prof. Soemantri Brodjonegoro No.1 Bandar Lampung 35143 \\ E-mail: solikhin.1962@fp.unila.ac.id
}

\begin{abstract}
ABSTRAK
Kajian jenis dan populasi tikus merupakan tahapan dasar yang sangat penting sebelum dilakukannya manajemen pengendalian hama. Informasi yang diperoleh dapat menjadi dasar pertimbangan dalam menentukan strategi pengendalian tikus yang efektif. Penelitian ini dilakukan untuk mempelajari jenis dan populasi tikus, serta intensitas serangan tikus di perkebunan nanas PT Great Giant Food (GGF). Penelitian dilakukan di perkebunan nanas PT GGF Terbanggi Besar, Lampung Tengah pada bulan Juni sampai dengan Agustus 2016. Penelitian ini menggunakan teknik survei purposive sampling dengan empat blok kebun yang dipilih sebagai sampel yaitu blok kebun yang berbatasan dengan perkebunan tebu PT GMP, berdekatan dengan gedung dan kantor, berdekatan dengan desa, dan blok kebun yang jauh dari perbatasan maupun gedung. Penelitian dilakukan menggunakan metode perangkap (trapping), berbentuk persegi panjang dengan ukuran $p x l \times t=30 \mathrm{~cm} \times 20 \mathrm{~cm} \times 15 \mathrm{~cm}$. Jumlah tikus terperangkap dan intensitas serangan dianalisis nilai tengah standar errornya. Populasi relatif dihitung dari presentase setiap jenis di tiap blok, sedangkan nisbah kelamin dihitung dengan membandingkan jumlah jantan/betina. Hasil penelitian menunjukkan bahwa terdapat dua jenis tikus yaitu Rattus argentiventer dan Rattus exulans. Populasi relatif tikus spesies Rattus argentiventer yaitu 66,7\% sedangkan spesies Rattus exulans yaitu 33,3\%. Intensitas serangan tikus tertinggi terdapat pada blok kebun yang berbatasan dengan perkebunan tebu PT GMP 0,68\% dan intensitas serangan tikus terendah pada blok kebun yang jauh dari perbatasan dan bangunan $0,22 \%$.
\end{abstract}

Kata kunci : jenis, nanas, populasi, tikus.

\section{PENDAHULUAN}

Tikus merupakan hewan mamalia yang menimbulkan gangguan bagi manusia di berbagai bidang. Pada bidang pertanian tikus menjadi ancaman bagi pengelola dalam usaha budidayanya, baik dalam komoditas pangan, hortikultura dan perkebunan. Secara umum, tikus mampu merusak tanaman budidaya dalam waktu singkat dan dapat menimbulkan kerugian. Menurut Priyambodo ( 1995), tikus dapat menyerang komoditas tanaman budidaya dalam berbagai fase pertumbuhan tanaman, mulai dari pembibitan, fase vegetatif, fase generatif, bahkan pada hasil panen di tempat penyimpanan.

Pembudidayaan nanas tidak terlepas dari berbagai macam gangguan, salah satunya adalah serangan hama tikus. Hama ini juga menjadi masalah di salah satu pekebunan swasta yang membudidayakan nanas dalam skala yang luas yaitu PT GGF. Menurut Tim Budidaya Nanas PT GGF (2008), tikus menyerang pertanaman nanas pada fase generatif. Namun, upaya pengendalian tikus masih sulit dilakukan oleh pihak perusahaan perkebunan tersebut, karena belum diketahui jenis dan populasi tikus yang menyerang pertanaman nanas.
Tindakan monitoring merupakan langkah awal sebelum dilakukannya manajemen pengendalian hama. Menurut Sudarsono (2013), dalam pengendalian hama sangat diperlukan informasi atau pengetahuan dasar tentang biologi, siklus musiman serta dinamika populasi hama yang akan kita kendalikan. Penelitian ini dilakukan untuk mengetahui jenis dan populasi tikus, serta intensitas serangan tikus di perkebunan nanas PT Great Giant Food.

\section{BAHAN DAN METODA}

Penelitian ini dilaksanakan di perkebunan nanas PT GGF (Plantation Group 1), Terbanggi Besar Lampung Tengah, mulai pada bulan Juni sampai dengan Agustus 2016. Alat-alat yang digunakan adalah meteran, perangkap tikus (Bubu), kertas plastik, kamera digital, toples, alat tulis, label dan buku kunci identifikasi tikus yang diterbitkan oleh Badan Penelitian dan Pengembangan Kesehatan (BP2K) Kementerian Kesehatan RI 2016. Bahan-bahan yang digunakan yaitu umpan perangkap, dan kloroform $37 \%$.

Metode yang digunakan adalah teknik survei purposive sampling dengan empat blok kebun yang 
dipilih sebagai sampel yaitu blok kebun yang berbatasan dengan perkebunan tebu GMP, berdekatan dengan gedung dan kantor, berdekatan dengan desa, dan blok kebun yang jauh dari perbatasan maupun gedung. Penelitian dilakukan menggunakan metode perangkap (trapping), berbentuk persegi panjang dengan ukuran $p \times l \times t=30 \mathrm{~cm} \times 20 \mathrm{~cm} \times 15 \mathrm{~cm}$.

Tahapan penelitian yang dilakukan yaitu penentuan lokasi pemasangan perangkap. Lokasi pemasangan dikelompokkan menjadi empat blok, masing-masing blok dipilih enam plot dan dalam satu plot dipasang 10 perangkap. Pemilihan plot dilakukan dengan sampling berdasarkan pengamatan plot yang dipilih yaitu plot yang terdapat atau berdekatan dengan sarang tikus, dan pertanaman nanas yang terserang oleh tikus. Umur tanaman nanas di empat blok dipilih pertanaman yang sudah memasuki fase generatif dan sudah diaplikasi forcing.

Pemasangan perangkap dilakukan secara bertahap dari plot pertama ke plot selanjutnya. Pemasangan dilakukan satu kali di tiap plot dan pengamatan dilakukan setiap hari selama lima hari Pada saat pengamatan, tikus yang terperangkap diamati dan diukur panjang total dari ujung hidung sampai ujung ekor, panjang ekor dari pangkal sampai ujung ekor, panjang telapak kaki belakang dari tumit sampai ujung kuku, panjang telinga dari pangkal daun telinga sampai ujung daun telinga, jumlah puting susu pada tikus betina di bagian dada dan perut, warna rambut badan, dan warna ekor. Identifikasi tikus menggunakan buku kunci identifikasi dalam buku Teknik Survei di Bidang Kesehatan. (BP2K) Kementerian Kesehatan RI Salatiga 2016. Pengangkatan perangkap dilakukan pada hari keenam, kemudian perangkap dibersihkan untuk dilakukan pemasangan di blok selanjutnya.

Pengamatan intensitas serangan tikus dilakukan dengan teknik lima mata dadu dengan sampel sebanyak 1000 tanaman. Teknik ini dilakukan dengan cara mengambil lima titik sampel pada masing-masing plot, yaitu empat titik di tepi plot dan satu titik di tengah plot. Masing-masing titik di sampling sebanyak 200 tanaman. Pengamatan liang dilakukan dengan memutari bagian tepi plot dan menghitung jumlah liang yang ditemukan.

Variabel yang diamati yaitu jenis tikus yang terperangkap, jumlah tikus terperangkap, populasi relatif tiap jenis tikus, nisbah kelamin, liang tikus, dan intensitas serangan. Data yang diperoleh dari jumlah tikus terperangkap dan intensitas serangan dianalisis nilai tengah standar errornya. Perhitungan intensitas serangan dihitung berdasarkan populasi relatif:

$$
P_{i}=\frac{n_{i}}{N} \times 100 \%
$$

Keterangan:

$\mathrm{p}_{\mathrm{i}}=$ populasi relatif jenis ke- $i$;

$\mathrm{n}_{\mathrm{i}}=$ kelimpahan jenis ke- $i$;

$\mathrm{N}=$ jumlah total seluruh individu.

Nisbah kelamin dihitung dengan membandingkan:

jumlah jantan/betina. $=\frac{\text { Jumlahjantan }}{\text { Jumlahbetin }}$

Dengan kriteria :

$>1=$ didominasi oleh jantan

$1=$ jantan dan betina seimbang

$<1=$ didominasi oleh betina

\section{HASIL DAN PEMBAHASAN}

\section{Jenis Tikus Terperangkap}

Berdasarkan hasil identifikasi tikus yang terperangkap di empat blok pengamatan, diperoleh tikus sebanyak 64 ekor, terdiri dari dua spesies tikus yaitu tikus jenis Rattus argentiventer dan Rattus exulans. Identifikasi dilakukan berdasarkan pengukuran morfologi kuantitatif dan pengamatan kualitatif morfologi tikus. Berdasarkan hasil identifiksi, tikus yang memiliki ciriciri yang tertera pada Tabel 1 sesuai dengan yang dipaparkan oleh Aplin dkk. (2003) bahwa tikus tersebut adalah jenis $R$. argentiventer, sedangkan tikus yang memliki ciri-ciri yang tertera pada Tabel 2 sesuai dengan yang dipaparkan oleh Priyambodo (1995) bahwa tikus tersebut adalah jenis $R$. exulans.

Tikus $R$. argentiventer dalam penyebarannya termasuk dalam jenis peridomestik, yaitu spesies tikus yang aktivitas hidupnya berada di lahan pertanian, perkebunan, dan sekitar pemukiman manusia. Namun, pada umumnya tikus ini memiliki habitat di sawah dan daerah-daerah yang berdekatan dengan sumber air irigasi. Menurut Sudarmaji dkk. (2008), tikus sawah merupakan hewan terestrial yang bersarang di daratan baik dengan membuat lubang di tanah untuk tempat tinggal atau berlindung di semak-semak yang rimbun.

$R$. argentiventer merupakan hewan yang pandai menggali tanah, yang dicirikan dengan panjang ekor yang relatif lebih pendek dari panjang badan, serta tonjolan pada kaki yang relatif kecil dan halus permukaannya. Tikus $R$. exulans dalam aktivitas hidupnya berada di kebun dan sekitar pemukiman manusia. Menurut Bianchi (1961) dan Kami (1966) am Williams (1973), bahwa $R$. exulans dominan di tiga habitat yaitu hutan hujan, padang rumput, dan perkebunan kelapa, namun tikus ini juga sering ditemukan pemukiman penduduk yang berdekatan dengan kebun. Aplin dkk (2003), menerangkan bahwa $R$. exulans merupakan hewan 
Tabel 1. Hasil identifikasi tikus jenis $R$. argentiventer

\begin{tabular}{llll}
\hline Pengamatan & Hasil Identifikasi & & Pustaka Aplin dkk. (2003) \\
\hline Panjang total (mm) & $240-360$ & (Gambar 1A) & $240-370$ \\
Panjang ekor (mm) & $120-180$ & (Gambar 1B) & $130-192$ \\
Panjang telapak kaki (mm) & $28-40$ & (Gambar 1C) & $32-39$ \\
Panjang telinga (mm) & $16-25$ & (Gambar 1D) & $18-21$ \\
Warna ekor atas dan bawah & coklat gelap & (Gambar 1E) & coklat gelap \\
Jumlah puting susu (dada) & 3 pasang & (Gambar 1F) & 3 pasang \\
Jumlah puting susu (perut) & 3 pasang & (Gambar 1G) & 3 pasang \\
Warna badan atas & kelabu kehitaman & (Gambar 1H) & Coklat kelabu kehitaman \\
Warna badan bawah & kelabu pucat & (Gambar 1H) & kelabu pucat \\
\hline
\end{tabular}

Tabel 2. Hasil identifikasi tikus jenis R. exulans

\begin{tabular}{|c|c|c|c|}
\hline Pengamatan & Hasil Identifikasi & & $\begin{array}{l}\text { Pustaka Priyambodo } \\
\text { (2003) }\end{array}$ \\
\hline Panjang total (mm) & $\begin{array}{l}160-360 \\
2 \mathrm{~A})\end{array}$ & (Gambar & $139-365$ \\
\hline Panjang ekor (mm) & $\begin{array}{l}90-160 \\
2 B)\end{array}$ & (Gambar & $108-147$ \\
\hline Panjang telapak kaki (mm) & $\begin{array}{l}18-31 \\
2 \mathrm{C})\end{array}$ & (Gambar & $24-31$ \\
\hline Panjang telinga $(\mathrm{mm})$ & $\begin{array}{l}15-23 \\
2 \mathrm{D})\end{array}$ & (Gambar & $11-20$ \\
\hline Warna ekor atas dan bawah & coklat gelap & (Gambar 2E) & coklat gelap \\
\hline Jumlah puting susu (dada) & 2 pasang & (Gambar 2F) & 2 pasang \\
\hline Jumlah puting susu (perut) & $\begin{array}{l}2 \text { pasang } \\
2 \mathrm{G})\end{array}$ & (Gambar & 2 pasang \\
\hline Warna badan atas & $\begin{array}{l}\text { kelabu kehitaman } \\
2 \mathrm{H})\end{array}$ & (Gambar & coklat gelap \\
\hline Warna badan bawah & $\begin{array}{l}\text { putih kelabu pucat } \\
2 \mathrm{H})\end{array}$ & (Gambar & Putih kelabu/pucat \\
\hline
\end{tabular}


Tabel 3. Jumlah tikus yang terperangkap di perkebunan nanas milik PT Great Giant Food

\begin{tabular}{rlc}
\hline No & Blok & $\begin{array}{c}\text { Rata-rata tikus terperangkap } \pm \mathrm{S} E \\
\text { (ekor/10 perangkap) }\end{array}$ \\
\hline 1 & Dekat GMP & $2,67 \pm 0,03$ \\
2 & Bagian Tengah & $1,50 \pm 0,03$ \\
3 & Dekat Gedung & $2,33 \pm 0,04$ \\
4 & Dekat Desa & $2,50 \pm 0,02$ \\
\hline
\end{tabular}

Tabel 4. Nisbah kelamin tikus yang terperangkap di perkebunan nanas milik PT Great Giant Food

\begin{tabular}{|c|c|c|c|c|c|c|c|}
\hline \multirow[b]{2}{*}{ No } & \multirow[b]{2}{*}{ Blok } & \multicolumn{3}{|c|}{ R. argentiventer } & \multicolumn{3}{|c|}{ R. exulans } \\
\hline & & $\begin{array}{l}\text { Jantan } \\
\text { (ekor) }\end{array}$ & $\begin{array}{l}\text { Betina } \\
\text { (ekor) }\end{array}$ & d/o & $\begin{array}{l}\text { Jantan } \\
\text { (ekor) }\end{array}$ & $\begin{array}{l}\text { Betina } \\
\text { (ekor) }\end{array}$ & olo \\
\hline 1 & Dekat GMP & 4 & 8 & 0,5 & 2 & 2 & 1 \\
\hline 2 & Bagian Tengah & 2 & 4 & 0,5 & 2 & 1 & 2 \\
\hline 3 & Dekat Gedung & 1 & 7 & 0,1 & 3 & 3 & 1 \\
\hline 4 & Dekat Desa & 2 & 7 & 0,3 & 3 & 3 & 1 \\
\hline
\end{tabular}

Tabel 5. Jumlah liang tikus di perkebunan nanas milik PT Great Giant Food

\begin{tabular}{clc}
\hline No & Blok & Jumlah Liang Tikus \\
\hline 1 & Dekat GMP & 174 \\
2 & Bagian Tengah & 132 \\
3 & Dekat Gedung & 137 \\
4 & Dekat Desa & 154 \\
\hline
\end{tabular}

arboreal. Tikus ini membuat sarang di sekitar pohon yang rendah, rerumputan yang padat, dan di sekitar rumah. R. exulans memiliki ciri-ciri ekor yang lebih panjang dari badannya dan terdapat tonjolan pada permukaan kaki yang besar dan kasar.

\section{Jumlah Tikus Terperangkap}

Hasil yang diperoleh dari pemasangan perangkap tikus menunjukan bahwa rata-rata jumlah tikus terperangkap di empat blok bervariasi antara 1,50-2,67 ekor per sepuluh perangkap (Tabel 3). Blok kebun yang berbatasan dengan GMP memiliki nilai rata-rata tikus terperangkap relatif lebih tinggi yaitu sebesar 2,67 $\pm 0,03$ ekor per sepuluh perangkap. Sedangkan blok yang berada di tengah kebun memiliki nilai rata-rata relatif lebih rendah dibandingkan dengan blok pengamatan lainnya, yaitu sebesar $1,50 \pm 0,03$ ekor per sepuluh perangkap.

Blok yang berbatasan dengan perkebunan tebu memiliki nilai rata-rata tikus tertangkap relatif lebih tinggi dibandingkan blok kebun lainnya. Blok ini berdekatan dengan pertanaman tebu yang masih berumur satu bulan dan lahan perkebunan tebu yang masih kosong.
Berdasarkan pengamatan kebun tebu di PT GMP, cara pemanenan tebu dilakukan dengan cara dibakar. Diduga bahwa saat pemanenan tebu, tikus yang berasal dari pertanaman tebu GMP bermigrasi ke pertanaman nanas PT GGF. Hal ini sesuai dengan pernyataan Priyambodo (1995) bahwa perkebunan tebu yang dipanen dengan cara dibakar mengakibatkan tikus bermigrasi ke daerah yang terdapat sumber pakan, seperti pemukiman warga, dan kebun di sekitarnya. Menurut Sudarmaji dkk (2008), migrasi tikus berkaitan dengan ketersediakan pakan. Pada saaat bera atau padi telah dipanen, $70 \%$ populasi tikus akan bermigrasi ke habitat pelarian yang menyediakan pakan (Perkebunan sayur/buah, pemukiman penduduk dan gudang), sedangkan 30\% sisanya akan menetap dengan bertahan hidup memanfaatkan sumber makanan yang ada.

Kondisi blok kebun yang berbatasan dengan desa dekat dengan pemukiman warga dan kebun singkong. Kebun singkong tersebut memiliki luas lahan sekitar 4 ha dengan umur tanaman dua bulan. Berdasarkan pernyataan di atas diduga kebun singkong tersebut menyediakan sumber makanan bagi tikus yang berhabitat di sekitar pemukiman warga dan kebun 
Tabel 6. Prediksi tanaman terserang di perkebunan nanas milik PT Great Giant Food

\begin{tabular}{llcccc}
\hline No & Blok & $\begin{array}{c}\text { Luas } \\
\text { lahan } \\
\left(\mathrm{m}^{2}\right)\end{array}$ & $\begin{array}{c}\text { Populasi tanaman / } \\
\text { Luas Lahan (buah) }\end{array}$ & $\begin{array}{c}\% \\
\text { Serangan }\end{array}$ & $\begin{array}{c}\text { Prediksi Buah } \\
\text { Terserang } \\
\text { (buah) }\end{array}$ \\
\hline 1 & Dekat GMP & 38.900 & 259.333 & 0,683 & 1.772 \\
2 & $\begin{array}{l}\text { Bagian } \\
\text { Tengah }\end{array}$ & 17.400 & 116.000 & 0,217 & 251 \\
3 & Dekat Gedung & 33.100 & 220.667 & 0,350 & 771 \\
4 & Dekat Desa & 27.900 & 596.000 & 0,583 & 1.085 \\
\hline
\end{tabular}

singkong. Namun saat tanaman singkong dipanen, tikus akan beralih ke perkebunan nanas untuk mencukupi kebutuhan pakannya. Menurut Priyambodo (1995), aktifitas harian tikus mencapai jarak rata-rata $30 \mathrm{~m}$ dan tidak sampai 200 m bila sumber pakan di sekitar tempat tinggal cukup memadai. Apabila pakan bagi tikus sudah tidak mencukupi, maka tikus akan melakukan migrasi dari habitat asli ke tempat sumber pakan yang dapat mencukupi kebutuhan pakannya. Jarak migrasi tikus dapat mencapai jarak lebih dari $700 \mathrm{~m}$.

Blok kebun yang berdekatan dengan gedung dan bangunan memiliki rata-rata tikus terperangkap sebesar 2,33 ekor per sepuluh perangkap. Kondisi blok berdekatan dengan gudang yang menyimpan alat mesin (alsin) pertanian, bengkel alsin, dan gudang penyimpanan bahan-bahan pestisida. Bangunan-bangunan tersebut rata-rata berukuran besar dan luas, selain itu terdapat alat-alat mesin yang tidak terpakai dan ditumpuk di belakang gudang. Kondisi tersebut mendukung tikus untuk bersarang, dan menghindari dari predator seperti ular dan burung hantu.

Blok kebun yang berada di tengah (jauh dari wilayah perbatasan dan gedung) memiliki nilai rata-rata tikus terperangkap relatif rendah dibandingkan dengan blok lainnya. Blok ini relatif homogen dengan keadaan vegetasi berupa pertanaman nanas dan lebung. Hal ini memungkinkan bahwa pada blok kebun yang berada di tengah hanya terdapat tikus yang berada di blok tersebut tanpa adanya tikus yang berasal dari wilayah lain, sehingga jumlah rata-rata tikus yang terperangkap relatif lebih rendah dibanding dengan blok lain.

\section{Populasi Relatif}

Berdasarkan Gambar 3, nilai populasi relatif tikus jenis $R$. argentiventer di empat blok kebun lebih tinggi dibandingkan dengan $R$. exulans. Hal ini menunjukkan bahwa populasi tikus di empat blok kebun didominasi oleh $R$. argentiventer. Menurut Sudarmaji dkk (2008), kompetisi sosial dalam memperebutkan teritorial dan betina memaksa tikus jantan yang kalah dalam berkompetisi untuk keluar dari kelompok dan membentuk kelompok baru. Hal ini yang menyebabkan penyebaran tikus merata, sehingga tikus sawah dapat menginvasi wilayah dalam hamparan yang luas.

Hasil pengamatan populasi relatif pada keempat blok kebun menunjukkan bahwa tikus jenis $R$. argentiventer yang umumnya memiliki habitat di sawah lebih mendominasi dibandingkan dengan $R$. exulan yang memiliki habitat di perkebunan. Keberadaan lebung menjadi salah salah satu faktor tikus jenis $R$. argentiventer dapat hidup di perkebunan nanas PT GGF. Lebung yang terdapat di setiap blok menjadi tempat yang cocok untuk tikus membuat sarang dan beraktivitas. Lebung ini berbentuk seperti danau dan dikelilingi oleh rumpun-rumpun bambu. Priyambodo (1995), menyatakan bahwa umumnya tikus jenis $R$. argentiventer dijumpai di daerah persawahan, sumber air irigasi, pekarangan, tanggul irigasi, dan padang alangalang. Sedangkan tikus jenis $R$. exulans umumnya dijumpai di semak-semak, ladang, pinggiran hutan dan pemukiman manusia.

\section{Nisbah Kelamin}

Hasil pengamatan nisbah kelamin tikus di empat blok kebun nanas menunjukkan bahwa tikus spesies $R$. argentiventer didominasi oleh tikus yang berkelamin betina, dengan nilai nisbah kurang dari 1. Sedangkan pada tikus spesies $R$. Exulans, terdapat perbedaan nilai nisbah kelamin tikus antara blok tengah dengan ketiga blok lainnya. Hal ini dapat dilihat dari nilai nisbah kelamin tikus pada blok tengah memiliki nilai lebih dari 1, menandakan bahwa tikus jantan lebih mendominasi, sedangkan pada ketiga blok lainnya nilai nisbah kelamin relatif seimbang yaitu sama dengan 1 .

Berdasarkan data nisbah kelamin (Tabel 4) dan data populasi relatif (Gambar 3), terlihat bahwa tikus spesies $R$. argentiventer yang didominasi oleh tikus berkelamin betina memiliki nilai populasi relatif tinggi. Sedangkan spesies $R$. exulans dengan nilai nisbah kelamin yang seimbang memiliki nilai populasi relatif 

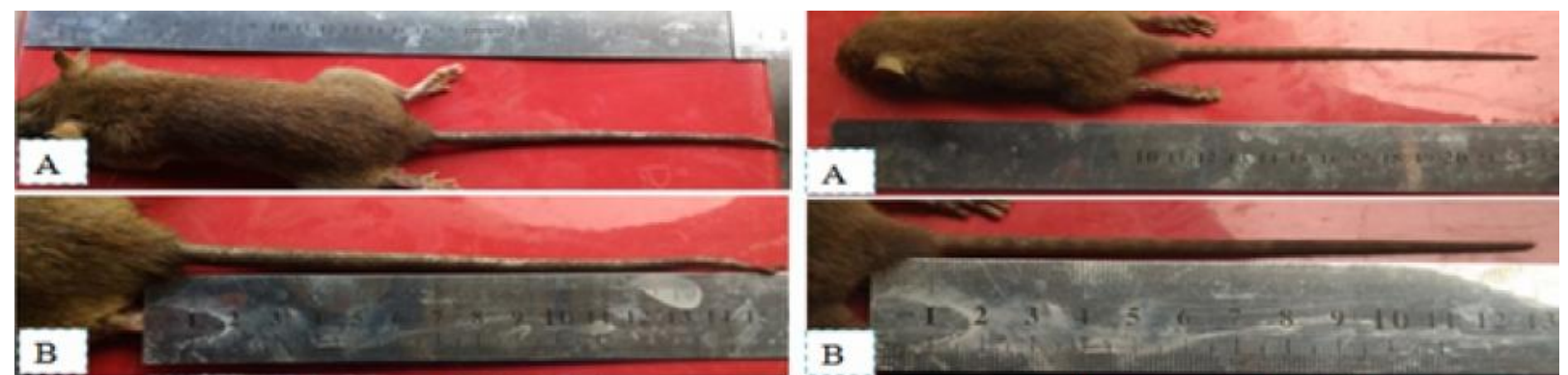

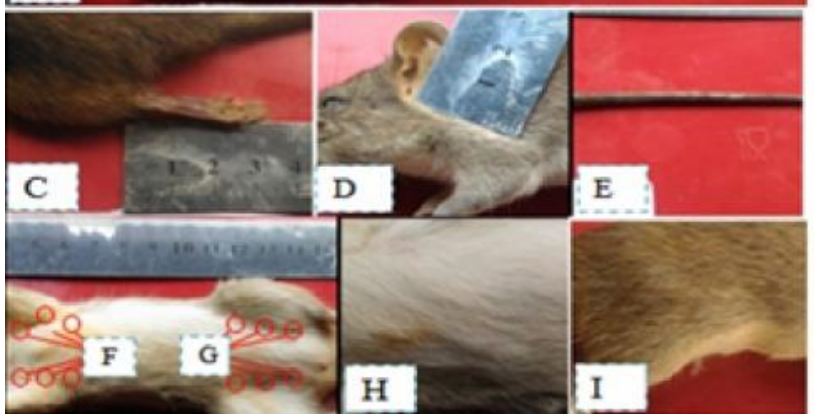

Gambar 1. Spesies Rattus argentiventer

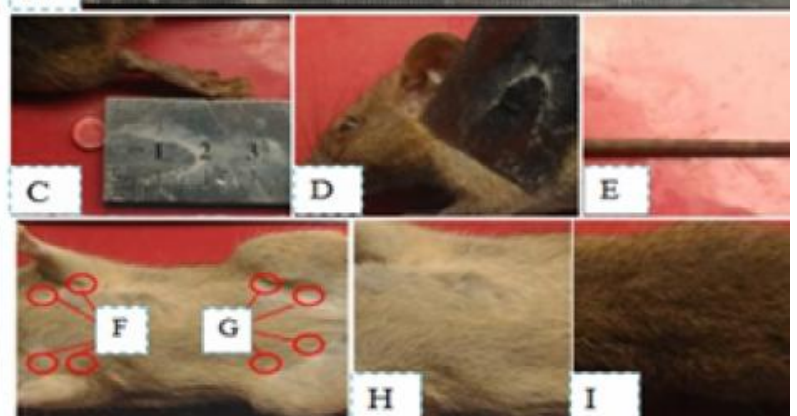

Gambar 2. Spesies tikus Rattus exulans

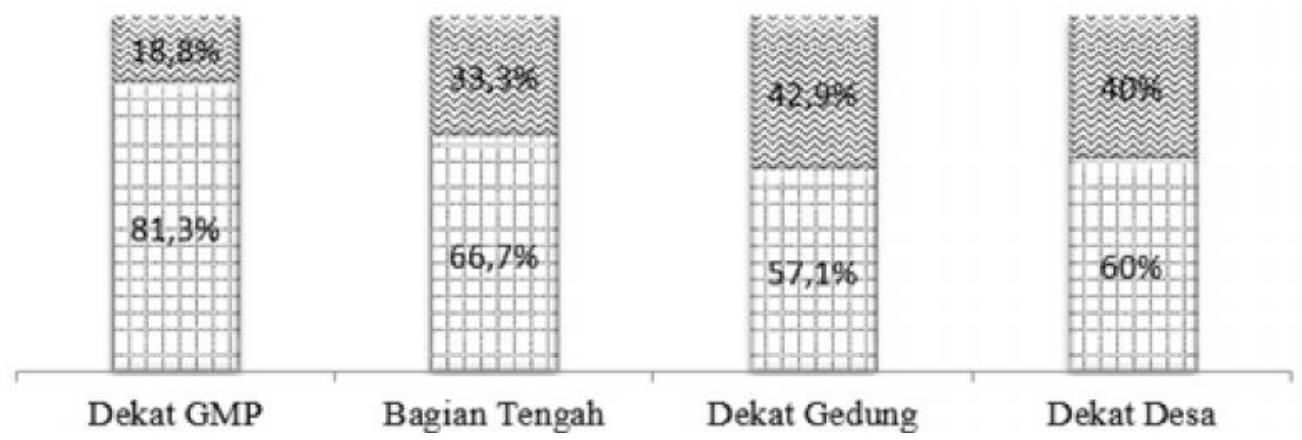

\& R. exulans

$\forall R$. argentiventer

Gambar 3. Populasi relatif tikus di perkebunan nanas PT Great Giant Food

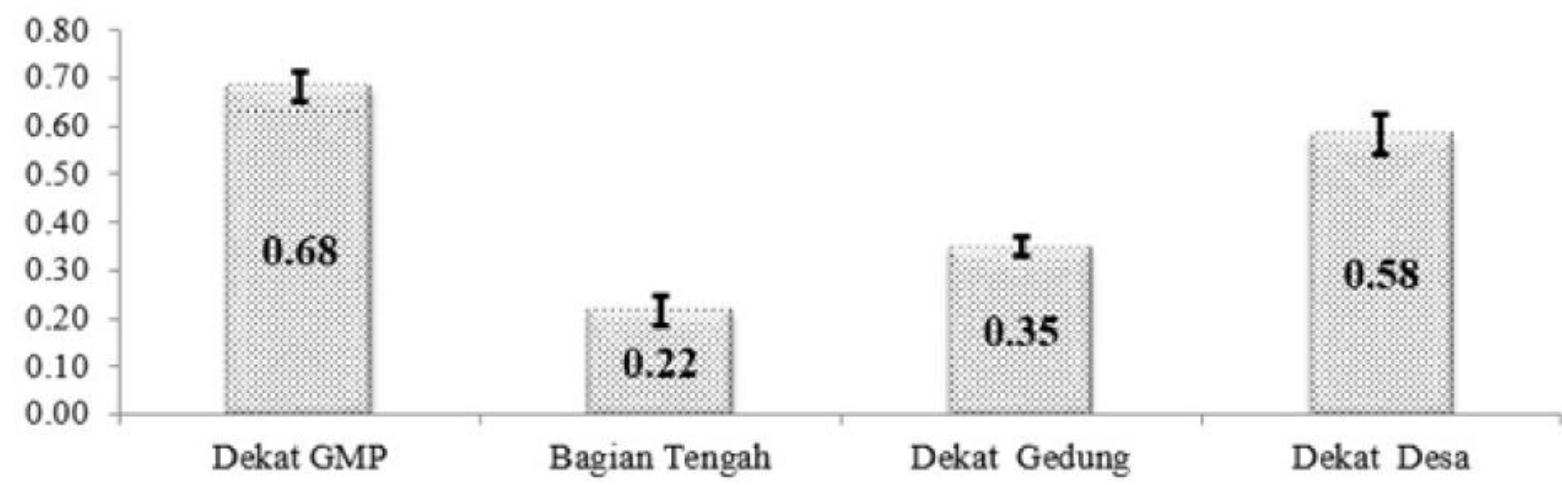

Gambar 4. Intensitas serangan tikus di perkebunan nanas milik PT Great Giant Food 
rendah. Diduga dominasi betina dan kemampuan reproduksi tiap jenis tikus mempengaruhi jumlah populasi. Menurut Priyambodo (1995), tikus $R$. argentiventer merupakan hewan yang mempunyai kemampuan reproduksi yang sangat tinggi. Hal ini ditunjang dengan beberapa faktor yaitu matang seksual yang cepat yaitu antara 2-3 bulan, masa bunting yang singkat yaitu antara 21-23 hari, timbulnya birahi kembali

24 - 48 jam setelah melahirkan, melahirkan keturunan yang banyak antara 3-12 ekor dengan ratarata 6 ekor per kelahiran. Bahkan untuk $R$. argentiventer dalam keadaan yang cukup pakan mampu melahirkan anak sebanyak 18 ekor.

Menurut Williams (1973) dan Aplin dkk. (2003), tikus jenis $R$. exulans memiliki kemampuan reproduksi yang cepat dengan lamanya masa bunting yaitu 23 hari, dan rata-rata kelahiran anak tikus berkisar antara 5-7 ekor. Berdasarkan ciri-ciri reproduksi diatas, kedua jenis tikus mempunyai potensi untuk meningkatkan populasinya dengan cepat, namun dominasi betina lebih berpengaruh dalam menambah jumlah kelahiran dalam populasi tiap jenis tikus.

\section{Liang Tikus}

Hasil pengamatan liang tikus (Tabel 5) di atas menunjukkan bahwa jumlah liang tikus terbanyak ditemukan pada blok yang berdekatan dengan PT GMP, yaitu sebanyak 174 liang tikus. Pada blok tengah jumlah liang yang ditemukan memiliki jumlah yang lebih sedikit yaitu 132 liang tikus. Liang yang menjadi sarang dan tempat tikus berlindung diduga menjadi faktor yang mendukung peningkatan populasi tikus dalam mencari makan dan menimbulkan serangan pada pertanaman nanas.

Berdasarkan data jumlah jumlah liang (Tabel 5) dan data intensitas serangan (Gambar 4) terlihat bahwa pada blok kebun dengan jumlah liang paling banyak memiliki intensitas serangan tikus yang tinggi, seperti pada blok kebun yang berbatasan dengan PT GMP dengan jumlah liang sebanyak 174 dan memiliki intensitas serangan yang sebesar $0,68 \%$. Sedangkan, pada blok dengan jumlah liang sedikit memiliki intensitas serangan tikus yang rendah, seperti pada blok kebun yang berada di tengah (jauh dari perbatasan dan gedung) dengan liang sebanyak 132, memiliki intensitas serangan sebesar $0,22 \%$.

\section{Intensitas Serangan Tikus}

Berdasarkan Gambar 4, intensitas serangan tikus di keempat blok pengamatan bervariasi antara 0,68$0,22 \%$. Pada blok kebun yang berabatasan dengan PT GMP memiliki intensitas lebih tinggi dibandingkan pada blok lainnya sebesar $0,68 \%$. Sedangkan blok yang berada ditengah memiliki intensitas serangan terendah yaitu $0,22 \%$. Dari data intensitas serangan dapat digunakan untuk mengetahui prediksi buah terserang di masing-masing blok.

Blok yang berbatasan dengan PT GMP memiliki intensitas serangan lebih tinggi dibanding ketiga blok lainnya yaitu sebesar $0,683 \%$ dan populasi tanaman sebanyak 259.333 buah, diprediksi banyaknya buah terserang sebesar 1.772 buah (Tabel 6). Sedangkan pada blok kebun yang berada di tengah dengan intensitas serangan tikus lebih rendah di bandingkan blok lainnya yaitu sebesar $0,217 \%$ dan populasi tanaman sebanyak 116.000 buah, diprediksi banyaknya buah yang terserang sebesar 251 buah.

\section{KESIMPULAN}

Berdasarkan hasil penelitian yang telah dilakukan dapat ditarik kesimpulan spesies tikus yang diperoleh dari hasil identifikasi yaitu tikus spesies Rattus argentiventer dan Rattus exulans. Populasi relatif tikus spesies Rattus argentiventer yaitu 66,7\% sedangkan spesies Rattus exulans yaitu 33,3\%. Rata-rata tikus terperangkap di masing-masing blok berkisar 1,50 sampai 2,67 ekor per sepuluh perangkap. Intensitas serangan tikus pada blok kebun yang berbatasan dengan PT GMP yaitu sebesar $0,68 \%$, berbatasan dengan desa sebesar $0,58 \%$, blok yang dekat dengan bangunan dan gedung sebesar $0,35 \%$, dan blok kebun yang berada di tengah (jauh dari perbatasan dan bangunan) sebesar $0,22 \%$.

\section{DAFTAR PUSTAKA}

Aplin, K.P., P.R. Brown, J. Jacob, C.J. Kreb, dan G.R. Singleton. 2003. Field Methods for Rodent Studies in Asia and the Indo-Pacific. Australian Centre for International Agricultural Research (ACIAR) Canberra, Australia. $223 \mathrm{Hlm}$.

Priyambodo, S. 1995. Pengendalian Hama Tikus Terpadu. PT Panebar Swadaya. Jakarta. 53 hlm

Sudarmaji dan Herawati, N. A. 2009. Ekologi Tikus Sawah dan Teknologi Pengendaliannya. Balai Besar Penelitian Tanaman Padi. 28 hlm.

Sudarsono, H. 2013. Pengembangan Informasi Bionomi Spesifik Lokasi Untuk Meningkatkan Kefektifan Pengendalian Hama Utama Komersial. Pidato Ilmu Pengukuhan Guru Besar 
Ilmu Hama Tumbuhan. Penerbit Universitas Lampung. Bandar Lampung.

Tim Budidaya Nanas PT GGF. 2008. Budidaya Nanas di PT Great Giant Food. PT Great Giant Food. Terbanggi Besar. $399 \mathrm{hlm}$.

Williams, J. M. 1973. The Ecology of Rattus exulans (Peale) Reviewed. Pacific Science.

27 (2) 120-127 hlm.

Yuliadi, B., Muhidin, dan Indriani, S. 2016. Tikus Jawa Teknik Survei di Bidang Kesehatan. Badan Penelitian dan pengembangan Kesehatan Kementrian Kesehatan RI. Salatiga. $114 \mathrm{hlm}$. 